\author{
И. Б. Иткин \\ Институт востоковедения РАН / \\ Нацииоальный исследовательский университет «Высшая школа экономики» (НИУ ВШЭ) \\ (Москва, Россия) \\ ilya.borisovich.itkin@gmail.com
}

\title{
НОВАТОР ЖУКОВСКИЙ И АРХАИСТ ПУШКИН (два этюда из истории русского поэтического языка)
}

В статье рассматривается отражение в стихах поэтов XVIII - первой половины XIX в. вариативности, существовавшей в соответствующий период времени в двух точках грамматической системы русского языка: в образовании деепричастий от приставочных глаголов на -йти (по модели вошед, пришед или по модели войдя, придя?) и в выборе ударного гласного в форме родительного падежа множественного числа существительного время (времян, времен (через ['э]) или времён?). Формы на -йдя вошли в русскую поэзию в конце 1780-х гг. благодаря Карамзину и поэтам его круга, в первую очередь И. И. Дмитриеву. В первые десятилетия XIX в. эти формы были уже достаточно распространены: они встречаются, в частности, в поздних произведениях Державина и Хвостова, а также в поэзии Жуковского «арзамасского» периода (1813-1818 гг.). На этом фоне удивительным выглядит полное отсутствие таких форм в поэзии Пушкина. Сопоставление с пушкинской прозой, в которой также абсолютно преобладают формы на -шед, позволяет заключить, что речь идет не о сознательной архаизации, а о реальном словоупотреблении. Что касается формы родительного падежа слова время, до начала 1830-х гг. основной была форма времен. Первоначально конкурировавшая с ней форма времян уже в 1820-е гг. воспринималась как явно устаревшая (или даже просто как «неправильная»); использование Пушкиным этой формы в «Евгении Онегине» вызвало возражения критиков, не понявших пародийного пушкинского замысла. В 1830-е годы в стихах А.И. Полежаева и В.И. Соколовского появляется форма времён, очень быстро получающая широкое распространение. Самый ранний ныне известный пример употребления формы времён, однако, принадлежит В.А. Жуковскому (поэма «Пери и ангел», 1821); в стихах Пушкина эта форма отсутствует. Таким образом, по обоим рассматриваемым параметрам язык Жуковского оказывается более близким к современной норме, чем язык Пушкина. Эти примеры показывают, что представление о Пушкине как о новаторе в области русского языка, будучи вполне справедливо в целом, тем не менее требует уточнения во многих деталях. 
Ключевые слова: А.С. Пушкин, В.А. Жуковский, русская поэзия, эволюция русского языка, грамматическая вариативность, архаизм, новаторство.

Настоящая статья во многом обязана своим названием знаменитой книге Ю. Н. Тынянова «Архаисты и новаторы» [Тынянов 1929], центральное место в которой занимает большая статья «Архаисты и Пушкин».

Формулировка «новатор Жуковский» едва ли может вызвать удивление: карамзинист и признанный глава русского романтизма, Василий Андреевич Жуковский обычно воспринимается именно как умеренный новатор, ср. известную формулировку того же Тынянова: «И в вопросах стиля и в вопросах тем, и в большом вопросе о лирических жанрах он занимает половинчатое положение новатора реформиста» [Тынянов 1929: 109].

Напротив, формулировка «архаист Пушкин», особенно применительно к собственно-языковой стороне творчества поэта, выглядит парадоксальной, почти эпатажной. Согласно широко распространенному мнению, в области языка Пушкин был безусловным революционером, намного опередившим свое время. Ср., например, два высказанных практически одновременно и почти дословно совпадающих суждения на этот счет: «Особенно интересно, что грамматика у Пушкина воспринимается как более современная, чем у многих авторов, писавших в одно с ним время и даже после него» [Добровольский 2001: 161]; «Пушкинская речь по своей грамматике во многих отношениях ближе к нынешнему языку, чем современные Пушкину и даже более поздние авторы» [Падучева 2001: 107].

Мы ни в коем случае не хотим сказать, что такая оценка ошибочна. Пушкин, безусловно, является создателем современного русского литературного языка не единственным, но, если можно так выразиться, «главным»; не будь в его поэзии и прозе множества новаторских черт, это было бы совершенно невозможно. Однако, как, наверное, всегда в подобных случаях, чем большее внимание исследователь уделяет отдельным деталям, тем более сложной предстает открывающаяся ему картина.

Наша работа посвящена двум чрезвычайно частным грамматическим сюжетам: образованию деепричастий от приставочных глаголов на -йти (далее - «u-деепричастия») и форме родительного падежа множественного числа существительного время. Оба они рассматриваются на материале русской поэзии XVIII - первой половины XIX в. Непосредственной связи между двумя этими сюжетами нет; объединяет их в первую очередь то, что в обоих случаях речь идет о процессе смены грамматической нормы, происходившем в том числе в период литературной деятельности Пушкина.

Можно сказать, что в плане тематики (но не в плане оценок, от которых мы старались полностью воздерживаться) наша работа следует рецензии на IV и V главы «Евгения Онегина», опубликованной в 1828 г. в московском журнале «Атеней», автор которой, скрывшийся за подписью «В.», коснулся обоих этих сюжетов. Замечания критика «Атенея», в свою очередь, рассмотрены в монографии 
И. Б. Серебряной [Серебряная 2012]. Далее в работе мы придерживаемся общепринятой атрибуции статьи в «Атенее» М. А. Дмитриеву (1796-1866); при этом, однако, кажется уместным привести справедливую оговорку Е.О. Ларионовой: «Прямых свидетельств авторства Дмитриева нет» [ППК 1828-1830: 349].

Основным источником данных для нас послужил Поэтический подкорпус Национального корпуса русского языка (далее - ПП НКРЯ). Разумеется, следует учитывать, что это собрание текстов содержит сведения далеко не обо всех поэтах, писавших и печатавшихся в тот или иной период времени, и не все стихотворения поэтов, в него включенных. Тем не менее, материал, представленный в Поэтическом подкорпусе, как кажется, можно считать в целом достаточно репрезентативным.

\section{И-деепричастия}

В современном русском языке деепричастия от глаголов на -йти образуются от основы настоящего времени (выступающей также в инфинитиве): войдя, перейдя, придя и т. д. Как известно, в ходе истории эти формы сменили формы совсем иного вида, образовывавшиеся бессуффиксальным способом от основы прошедшего времени: вошед, перешед, пришед и т.д. Процесс вытеснения форм на -шед (далее - «ш-формы») фор-

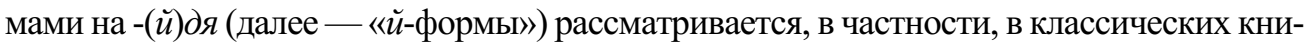
гах Л.А. Булаховского [Булаховский 1948: 128] и С.П. Обнорского [Обнорский 1953: 218-219], в недавней диссертации Л.Р. Абдулхаковой [Абдулхакова 2007]. В работе Л. А. Булаховского имеется важное упоминание о том, что «Г р е ч указывал (§ 247 , примечание 72) ${ }^{1}$ как на неправильное образование - на форму деепричастия совершенного вида войдя [Булаховский 1948: 128] »². Однако следующее непосредственно за этим утверждение - «В языке писателей его времени, действительно, в употреблении почти исключительно вошед и под.» [там же], — как будет ясно из дальнейшего изложения, нуждается в существенной корректировке; см. также ниже о возможной причине такой аберрации. С.П. Обнорский приходит к выводу о том, что «их (u-форм. - И.И.) полное изжитие литературным языком, как видно из данного материала, принадлежит половине XIX в.» [Обнорский 1953: 219], т.е. относится как раз к концу рассматриваемого нами хронологического периода. При этом, однако, все известные нам работы затрагивают данное грамматическое изменение очень кратко и общо, почти не касаясь стихотворных текстов и тем более не обращаясь к предпочтениям конкретных авторов; мы, напротив, в значительной степени сосредоточимся именно на этом вопросе.

Помимо $u$-форм и $\check{u}$-форм, $u$-деепричастия могут образовываться также по модели с суффиксом -ши: вошедши, пришедши и т. д.; такие формы встречаются в русской поэзии (хотя и не очень часто) на всем протяжении XVIII-XIX вв. Однако

1 [Греч 1827: 229-230]. Та же оценка («Сіе образованіе непозволительно, и противно правиламъ языка») повторена и во втором издании 1834 г. (§ 246, прим. 77) [Греч 1834: 214-215].

2 Здесь и далее все шрифтовые выделения принадлежат авторам цитат, если не оговорено иное. 
в поэзии, в отличие от прозы, формы на -ши не конкурируют напрямую с $u$-формами и $\check{u}$-формами, поскольку отличаются от них по числу слогов. Таким образом, в настоящей работе формы на -ши специально не рассматриваются, хотя и могут при необходимости привлекаться для сравнения.

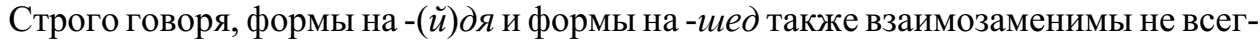
да. Во-первых, они могут стоять в позиции рифмы. Во-вторых, у форм на -шед, содержащих беглое $о$, есть варианты без этого о (вщед, обшед, подшед и т. д.), тогда как для соответствующих им форм на -йдя подобное невозможно. Употребления, не допускающие взаимозамены, мы будем называть «вынужденными»; для поэтов, у которых общее число $и$-форм велико (Державина, Муравьева, Жуковского, Пушкина, также Гнедича как переводчика «Илиады»), наличие среди них вынужденных может специально не оговариваться. Тем не менее в существенном большинстве случаев выбор между $и$-формой и $\breve{u-ф о р м о и ̆ ~ о п р е д е л я е т с я ~ и с к л ю ч и т е л ь-~}$ но личными предпочтениями поэта.

Несколько лет назад вопрос о соотношении $u$ - и $\check{u}$-форм привлек внимание лингвистов в неожиданном ракурсе - в связи с дискуссией об авторстве сказки «Конек-Горбунок» [Касаткин, Касаткина 2012а, 2012б; Перцов 2015] 3 . Несмотря на то, что в настоящее время эту «дискуссию», хотелось бы надеяться, можно считать завершенной (собственно говоря, она и не должна была быть начата), мы останавливаемся в том числе и на этом вопросе.

Для каждого из поэтов, творчество которых мы рассматриваем индивидуально, сначала указывается количество встретившихся в его стихах $u$-форм, через двоеточие - количество $\breve{u}$-форм. Обозначение « $1^{2} »$ используется в тех случаях, когда та или иная форма встретилась в стихотворении два раза, но в составе повторяющегося фрагмента, т. е. фактически речь идет об одном вхождении. Знак «х» означает «(столько-то) раз».

Изложение в целом ведется в порядке от более старших поэтов к более младшим, но без строгой упорядоченности по датам рождения, а скорее в соответствии с общей динамикой происходящих изменений.

\section{Н.М. Карамзин (1766-1826): 0:12.}

На протяжении почти всего XVIII в. в русской поэзии встречаются исключительно $u$-формы; так обстоит дело, в частности, у В.К. Тредиаковского, А. Д. Кантемира, М.В. Ломоносова, А.П. Сумарокова, И.С. Баркова, М.М. Хераскова, И. Ф. Богдановича.

В стихотворении «Анакреонтические стихи А.А. П<етрову>» $(1788$, опубл. 1789) в составе дважды повторенного (с небольшой вариацией) фрагмента встретилась форма найдя. В том, что первое употребление в стихах й-формы принадлежит

${ }^{3}$ На это обстоятельство нам указала С. В. Дьяченко (устное сообщение), которой мы выражаем самую искреннюю благодарность. 
Карамзину, нет ничего удивительного и даже ничего особенно примечательного. Едва ли не более важным представляется жанр «Анакреонтических стихов...»их принадлежность к числу «легких» дружеских посланий.

И. И. Дмитриев (1760-1837): 2:5.

С 1789 по 1810 г. й-формы 5х (включая прозаическую ремарку в идиллии «Две гробницы») встречаются в произведениях И.И. Дмитриева - поэта, близкого по взглядам к Карамзину и при этом даже несколько более старшего. С учетом того, что среди этих произведений - знаменитая «Причудница» (1794) и одна из лучших басен Дмитриева «Старик и трое молодых» (1795), не будет преувеличением сказать, что полноценное вхождение $\check{u}$-форм в русскую поэзию состоялось именно благодаря Дмитриеву.

Что касается двух $u$-форм, употребленных Дмитриевым, то одна из них (превзошед) встретилась в рифме и является вынужденной, а другая (пришед в тех же «Двух гробницах») требует специального рассмотрения. Как показывают данные ПП НКРЯ, распространение формы придя происходит с существенным запозданием относительно других й-форм: первое ее вхождение относится к 1828 г. (у К.П. Масальского), второе - только к 1845 г. (у молодого Аполлона Майкова). Причиной этого может быть как высокая частотность глагола прийти, так и некоторая морфонологическая нестандартность формы придя по сравнению с другими $\check{u}$-формами (отсутствие $\breve{u}$ ). Косвенным свидетельством того, что такое запоздание действительно имело место, могут служить «Записки» М. П. Загряжского (ок. 1770-1836; написаны не ранее 1826 г.): деепричастия от всех глаголов на -йти, кроме прийти, представлены в «Записках» только й-формами (11 раз), тогда как форма придя (встретилась 3х) конкурирует с формой пришедии (4x).

Вскоре после выхода стихотворений Карамзина и Дмитриева, во второй половине 1790-х — 1800-х гг., й-формы появляются в произведениях Ю.А. Нелединского-Мелецкого, Н.П. Николева, совсем юного П. А. Катенина и ряда других, менее известных поэтов. Отдельного упоминания заслуживает употребление формы войдя в выдержанной в весьма торжественном тоне «Оде Александру I» (1801) С.А. Москотильникова (1768-1852).

\section{Г.Р. Державин (1743-1816): 12:1.}

Державин был значительно старше и Карамзина, и даже Дмитриева: абсолютное преобладание в его поэзии $u$-форм вполне соответствует языку его времени. Тем более интересно, что в позднем стихотворении «Евгению. Жизнь Званская» (1807) поэт все же употребил форму пройдя. «Жизнь Званская» представляет собой послание, адресованное другу Державина епископу Евгению Болховитинову, т. е. написана в том же жанре, что и «Анакреонтические стихи...» Карамзина.

Отметим, что единственный пример $ш$-формы, имеющийся в стихах Державина, написанных позже «Жизни Званской», а именно в стихотворении «Обитель Добрады» (1808), является вынужденным (сшед). 
Д.И. Хвостов (1757-1835): 2:2.

В стихах Хвостова $u$-формы встретились в 1820 и 1821 гг., $\check{u}$-формы в 1824-1825 и 1834 гг.; возможно, в поздние годы граф сознательно старался следовать «новейшим тенденциям». Существенно также, что одно из стихотворений, где представлена $\breve{u}$-форма, хотя и выдержано в несколько ином роде, чем та же «Жизнь Званская», тем не менее также относится к жанру посланий это легендарное «Послание к N. N. о наводнении Петрополя, бывшем 1824 года 7 ноября».

\section{М.Н. Муравьев (1757-1807): 11:0.}

М.Н. Муравьев был поэтом и прозаиком, близким к сентиментализму и предромантизму, учителем Батюшкова; некоторые источники даже именуют его «основоположником жанра легкой поэзии в России». Тем не менее, $\breve{u}$-формы в его языке, судя по всему, не существовали вообще; отметим, правда, что все примеры $u$-деепричастий в его стихах относятся к 1770-м - 1780-м гг.

\section{И.А. Крылов (1769-1844): 2:0.}

Любопытно, что оба примера $u$-форм у Крылова встретились в одном и том же контексте: вышед из терпенья. По данным Основного подкорпуса НКРЯ, выражение вышед из терпения было достаточно употребительным вплоть до 20-х 30-х гг. XIX в., тогда как вариант выйдя из терпения фиксируется значительно позже, с 1870-х - 1880-х гг.

\section{А.Ф. Воейков (1778(1779?)-1839): 1:0. \\ Снилось мне, что в Петрограде, Чрез Обухов мост пешком \\ Перешед, спешу к ограде - И вступаю в Желтый Дом. («Дом сумасшедших», 1814-1839)}

Разумеется, со статистической точки зрения единичный пример $u$-формы, встретившийся в стихах Воейкова, непоказателен. См., однако, ниже о возможном отражении этих строк в творчестве других поэтов.

\section{Н.И. Гнедич (1784-1833): $1^{2}: 1$ <без учета перевода «Илиады»>.}

Деепричастие взошед употреблено Гнедичем в «высокой» поэме «Рождение Гомера» (1816), деепричастие выйдя - в пародийном стихотворении «Циклоп» (с подзаголовком «Феокритова идиллия, приноровленная к нашим нравам»; 1813), написанном в форме послания Батюшкову.

\section{Н.И. Гнедич, перевод «Илиады» (1829): $\approx 20: 2$.}

В переводе «Илиады» абсолютно преобладают $и$-формы; едва ли можно сомневаться в том, что такая картина представляет собой одно из проявлений общей установки Гнедича на архаизацию языка перевода. 


\section{В.А. Жуковский (1783-1852): 22:4 <без учета перевода «Одиссеи»>.}

Если $u$-формы встречаются в стихах Жуковского на протяжении полувека от юношеского «К Тибуллу» (1800) до последней неоконченной поэмы «Странствующий жид» (1851-1852), - то $\breve{u-ф о р м ы ~ н е ~ т о л ь к о ~ к у д а ~ м е н е е ~ м н о г о ч и с л е н н ы, ~}$ но и, что еще важнее, ограничены достаточно узкими хронологическими и жанровыми рамками.

С учетом сказанного выше едва ли стоит считать простым совпадением тот факт, что впервые $\breve{u}$-форма (пройдя) появляется у Жуковского в послании «К Ив.Ив. Дмитриеву» (1813); скорее перед нами своего рода оммаж старшему другу и собрату. Еще две формы (зайдя, войдя) встретились в третьей части послания «К Варваре Павловне Ушаковой и гр. Прасковье Александровне Хилковой» (1818). Наконец, форма дойдя имеется в стихотворении «Ноябрь, зимы посол, подчас лихой старик...» (1814); хотя это стихотворение не имеет обозначенного адресата, фактически оно также представляет собой послание, обращенное, по-видимому, к кому-то из родных ([Жуковский 1999: 727]; комментарий принадлежит О. Б. Лебедевой).

Как видно, «й-период» в творчестве Жуковского находит себе достаточно четкое соответствие в его биографии. Это время наиболее тесного дружеского и даже «игрового» общения поэта с другими карамзинистами, время становления и расцвета «арзамасского братства». «Арзамасское братство возникло в начале $1810-\mathrm{x}$ годов $<\ldots>$. Апогеем существования арзамасского братства явилось образование «Арзамаса» (1815-1818). Распад «Арзамаса» совпал с расслоением арзамасского братства на оппозиционное и лояльное направления. Умеренное крыло арзамасского братства возглавили Карамзин, Жуковский и Блудов...» [Гиллельсон 1974: $143]^{4}$. И.И. Дмитриев в период существования «Арзамаса» жил в Москве и не принимал участия в его деятельности; тем не менее на одном из заседаний общества он был избран его почетным членом, наряду, в частности, с Карамзиным и Нелединским-Мелецким [там же: 104-105].

\section{В. А. Жуковский, перевод «Одиссеи» (1849): $\approx 40: 2$.}

В том, что касается употребления $u$-деепричастий, Жуковский как переводчик Гомера следует Гнедичу с поистине удивительной точностью: в его переводе единичные формы на -йдя также смотрятся случайными отклонениями на фоне абсолютно преобладающих (даже еще более многочисленных, чем у Гнедича) форм на -шед.

\section{К.Н. Батюшков (1787-1855): 1:1.}

В 1810 г. в стихах Батюшкова встретилась форма пришед, в 1816-1817 гг. форма пройдя. Как отмечено выше, неупотребление поэтом формы придя может

${ }^{4}$ Разумеется, в рамках настоящей статьи мы не имеем возможности обсуждать «литературно-политические» оценки М.И. Гиллельсона, да и не считаем себя достаточно компетентными в этой области. Что же касается приводимых исследователем датировок, они, как представляется, не вызывают сомнений. 
и не быть случайным, однако надежных доказательств этому нет: в своих прозаических очерках Батюшков употребляет только $\check{u}$-формы, но деепричастие от глагола прийти в его прозе не представлено.

\section{К.Ф. Рылеев (1795-1826): 2:2 .}

В стихах Рылеева представлены, с одной стороны, форма вошед (1822, 1825), с другой - формы войдя (1821-1822) и подойдя (1825). Последние две стоят в позиции рифмы и, соответственно, являются вынужденными; тем не менее, они показывают, что Рылеев, несмотря на склонность к архаике, $\check{u}$-форм полностью не избегал.

\section{А. С. Пушкин (1799-1837): 12:0.}

В поэзии Пушкина $u$-формы встречаются на протяжении почти 20 лет -

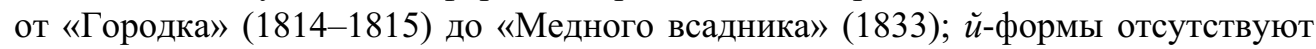
вообще. Единственный пример формы на -ши (взошедии) обнаруживается в одном из самых ранних стихотворений — «Монах» (1813) — и может быть просто данью традиции; таких форм довольно много, в частности, у Державина. Для поэта, родившегося в самом конце XVIII века, эта картина поистине поразительна; отражает ли она реальное пушкинское словоупотребление, или же Пушкин в своих стихах сознательно отдавал предпочтение устаревающей модели?

Обращение к прозе однозначно свидетельствует в пользу первого варианта. Как и в поэзии, в прозе Пушкина $u$-формы встречаются начиная с Лицея и до последних лет жизни; их довольно много в том числе в дневниковых записях, едва ли предназначавшихся для печати. В общей сложности $u$-формы засвидетельствованы в пушкинской прозе более 50х. Напротив, формы на -ши и й-формы немногочисленны (3 и 5 примеров соответственно) и появляются в прозе лишь в 30-е годы, причем последние - только в нехудожественных текстах (черновик письма А.Х. Бенкендорфу, «История Пугачева», подготовительные материалы к «Истории Петра»).

Любопытным образом, в подтверждение своего тезиса о том, что во времена Греча в русской литературе употреблялись почти исключительно $u$-формы (см. выше), Л.А. Булаховский приводит один-единственный пример, взятый из пушкинского «Гробовщика» [Булаховский 1948: 128]. Возможно, ученый был подспудно убежден, что если уж у Пушкина в роли $u$-деепричастий выступают архаичные формы, то у его современников - и подавно.

Форму нашед, встретившуюся в монологе главного героя в IV главе «Евгения Онегина», автор критической статьи в журнале «Атеней» снабдил следующим замечанием: «Нашед в разговорном слоге неупотребительно». Комментируя это высказывание, И.Б. Серебряная пишет: «Критик не назвал форму, которая, на его взгляд, была бы более предпочтительной в данном контексте. Но можно с достаточной степенью уверенности предположить, что это форма на -ии (нашедши) <..> Формы на -ии в своих мемуарах «Мелочи из запаса моей памяти» употреблял и сам Дмитриев» [Серебряная 2012: 40-41]. Отсылка к прозаическим сочинениям 
Дмитриева представляется вполне оправданной (что касается поэзии, в известных нам стихотворениях Дмитриева ни одного $u$-деепричастия нет); при этом, однако, исследовательница странным образом не учитывает того обстоятельства, что замена нашед на нашедши была бы метрически невозможна. Соответственно, ход мысли критика гипотетически может быть реконструирован следующим образом: Дмитриев не привел никакого конкретного варианта исправления данной строки, поскольку видел, что форма нашедии не подходит по размеру, а форму найдя считал, наоборот, «слишком разговорной» (в ряде отношений Дмитриев-племянник был куда более консервативен, чем его карамзинист-дядя).

Начальная строка первого восьмистишия из цикла «На картинки к «Евгению Онегину» в «Невском Альманахе»» — Вот перешед чрез мост Кокушкин... — обнаруживает близкое сходство с процитированной выше строфой Воейкова. Знакомство Пушкина с «Домом сумасшедших» подтверждается свидетельствами современников ([Черейский 1988: 73] со ссылкой на П.И. Бартенева). Рассматриваемое восьмистишие представляет собой автоэпиграмму; перекличкой с Воейковым (если она действительно имеет место) Пушкин, возможно, хотел усилить обращенную на самого себя иронию этих строк.

\section{Е. П. Ростопчина (1811-1858): 1:2.}

В двух ранних (1830 и 1836 гг.) стихотворениях Ростопчиной представлены й-формы войдя и пройдя, тогда как в сатире «Дом сумасшедших в 1858 году» имеется следующая строфа:

Комитет, прошед с вниманьем

Умственных недугов дом,

Беспристрастным совещаньем

Тайно занялся потом...

Поскольку «Дом...» Ростопчиной отнюдь не написан в архаизирующем стиле, появление в его тексте формы прошед едва ли может объясняться иначе, нежели прямой отсылкой все к той же строфе Воейкова. При этом для Ростопчиной, в отличие от Пушкина, употребленная Воейковым $u$-форма, по-видимому, была уже чужда.

\section{А. И. Полежаев (1804-1838): 2:1.}

Случай Полежаева примечателен тем, что формы выщед, пришед и сойдя встретились у него в одном и том же произведении - поэме «Эрпели» (1830), где, кроме того, представлены формы пришедии и прошедши. Как кажется, это дает нам основания с достаточной долей уверенности утверждать, что в языке Полежаева все три способа образования $u$-деепричастий были более или менее равноправны.

М. Ю. Лермонтов (1814-1841): 1:9.

Единственная $u$-форма (нашед) обнаруживается в поэзии Лермонтова в 1828 г. («Корсар»). В более поздних произведениях, начиная с «Джюлио» (1830), представлены только й-формы (в общий подсчет включены три ремарки к драме «Маскарад»). 
Наиболее правдоподобное объяснение такого соотношения, на наш взгляд, состоит в следующем: для собственного идиолекта Лермонтова нормой были уже й-формы, а форма намед была позаимствована начинающим поэтом «из книг», вероятнее всего - у Пушкина. Из сочинений Пушкина, опубликованных до написания «Корсара», эта форма встречается в IV главе «Евгения Онегина» (см. выше) и в таком важном для Лермонтова произведении, как «Кавказский пленник».

\section{П.П. Ершов (1815-1869): 1:0 $\rightarrow$ 0:0.}

В первом издании «Конька-Горбунка» (1834) встретилась форма общед; в существенно переработанном пятом издании (1856) этой формы нет. Л. Л. и Р. Ф. Касаткины считают этот факт одним из свидетельств того, что «Конек-Горбунок» написан Пушкиным, поскольку сибиряк Ершов якобы «не мог знать» такой формы [Касаткин, Касаткина 2012а: 31, 2012б: 276]. Данный аргумент несостоятелен уже потому, что Ершов не заменил «чуждое» ему (И) обшед... на Обойдя..., а просто изменил соответствующее место текста настолько сильно, что в нем вообще не оказалось глагола обойти. Если же рассматривать все поэтическое творчество Ершова в целом, то, как совершенно справедливо отмечает Н. В. Перцов, «форма деепричастия пришедши есть в «Сибирском казаке», а для приставочных глаголов от $и д т и$ форм деепричастий на -я у Ершова в известных нам текстах нет» [Перцов 2015: 597]. Однако дело, разумеется, не только в этом. Утверждение о том, что Ершов не мог знать форм на -шед, совершенно фантастично: с тем же успехом их «не мог знать», например, 14-летний Лермонтов или молодой Гончаров, как известно, родившийся в Симбирске: в его ранней повести «Лихая болесть» (1838) встретилась форма вышед. Трактовка Л. Л. и Р.Ф. Касаткиными форм на -шед как специфической черты северо-западных говоров также не выдерживает никакой критики; показательно, что, ссылаясь на книгу С.П. Обнорского в связи с примерами из Пушкина, они «не дочитали» соответствующий раздел до следующего замечания: «Спорадические свидетельства об этом типе форм можно встретить и в диалектном распространении: не дошедь дому. Колым. (Богор. 46)...» [Обнорский 1953: 219] (выделено нами. - И.И.).

\section{В. Г. Бенедиктов (1807-1873): 1:1.}

В поэзии второй половины XIX в. $u$-формы встречаются редко и почти исключительно как подчеркнутые церковнославянизмы. Показателен пример В.Г. Бенедиктова, у которого формы прешед и отойдя представлены почти одновременно, но первая из них употреблена в стихотворении на библейский сюжет («Исход», 1856), а вторая — в грустно-шутливой зарисовке с натуры («Елка», 1857).

\section{А. К. Толстой (1817-1875): 2:0.}

Поэзия А.К. Толстого на этом фоне выглядит исключением. Скорее всего, однако, дело здесь не в том, что Толстой был носителем какой-то особенно архаичной нормы, а в его жанровых предпочтениях: формы взошед и вышед встретились соответственно в балладе «Ругевит» (1870) и поэме «Дракон» (1875), действие 
которых происходит в далеком прошлом, что и объясняет некоторую приподнятость слога. Такое предположение подтверждается тем, что в историческом романе «Князь Серебряный» (1861-1863), написанном по большей части обычным, не стилизованным языком, 4 х представлены $\check{u}$-формы, $3 \mathrm{x}$ - формы на - $и и$, а $u$-форм нет совсем.

\section{М. И. Цветаева (1892-1941): 4:2.}

Среди поэтов еще более позднего времени отчетливо выделяется Марина Цветаева, у которой $u$-формы встречаются вдвое чаще, чем ц̆-формы, и представлены в четырех разных произведениях. Три из шести форм - сшед («Автобус», 1934 1936), знаменитое сошед в рифме в «Попытке ревности» (1924) и войдя также в рифме («И если где прольются слезы...», 1919-1920) - вынужденные, но в целом речь, безусловно, идет о последовательной стилизации под грамматику «Золотого века», возможно, вдохновленной непосредственно Пушкиным.

Таким образом, можно утверждать, что формы на -йдя были введены в русскую поэзию Н.М. Карамзиным и его единомышленниками, в первую очередь И.И. Дмитриевым, в конце XVIII века. На протяжении примерно 40-50 лет $u$-формы и $\breve{u}$-формы сосуществовали как более или менее равноправные варианты. У тех поэтов, для которых модель на -йдя не была единственно возможной или преобладающей (Державин, Хвостов, Гнедич, Жуковский), обнаруживается несомненная склонность к ее использованию в дружеских посланиях - не столько под прямым влиянием «Анакреонтических стихов...» Карамзина, сколько в соответствии с общими представлениями об этом жанре как допускающем (и даже предполагающем) большую по сравнению с другими жанрами близость к разговорному языку.

\section{Род. пад. мн. ч. слова время}

В том же критическом разборе IV и V глав «Евгения Онегина», опубликованном в 1828 г. в журнале «Атеней», есть следующий пассаж:

«Но эта важная забава

Достойна старых обезьян

Хваленых дедовских времян <...

Следственно, Державин ошибся, сказав:

Глагол времен».

И.Б. Серебряная комментирует эту эскападу следующим образом: «Ставшая объектом критики форма времян < ..> сама по себе вовсе не была необычной. <..> В Национальном корпусе русского языка имеется свыше 40 случаев использования этой формы, как в стихотворных, так и в прозаических текстах XVIII - 1-й половины XIX вв. <..> Думается, что негативная реакция Дмитриева на форму времян была вызвана не столько непривычностью этой падежной формы, сколько её 
нетипичным и даже не вполне приличным по тем временам употреблением. Нарушив устойчивую традицию, Пушкин включил книжную форму времян в стилистически сниженный контекст и, срифмовав со словом обезьян, лишил данное образование обычного ореола возвышенности» [Серебряная 2012: 36].

Приведенное объяснение спорно. И рифма времян - обезьян, и общая тональность пушкинских строк, безусловно, были намеренно шокирующими, однако если у Дмитриева имелись какие-то претензии именно на этот счет, совершенно непонятно, что мешало ему высказать их более или менее прямо. На наш взгляд, куда проще предположить, что Дмитриев написал именно то, что хотел написать: форма времян (независимо от рифмы и контекста) казалась критику даже не устаревшей, а просто неправильной, и вполне естественно, что в подтверждение своей точки зрения он привел цитату из хрестоматийного стихотворения такого авторитетного поэта, как Державин. Добавим, что у Державина форма времян действительно не встречается вовсе, а в написанном значительно позже стихотворении Дмитриева «Песнь правде» (1842) использована традиционная рифменная пара времен племен.

Что касается «обычности» или «необычности» формы времян, приведенная И. Б. Серебряной статистика непоказательна, поскольку не учитывает хронологическую динамику ее употребления. Между тем, данные ПП НКРЯ свидетельствуют о том, что появление формы времян в «Евгении Онегине» было в русской поэзии той эпохи последним: в следующий раз она обнаруживается в 1897 (!) г. в пародийно-сатирическом стихотворении В.С. Соловьева «Уносит все река времян...». Таким образом, к середине 1820-х годов эта форма уже фактически «выбыла из игры», и обращение к ней Пушкина действительно не могло не казаться читателям и критикам несколько странным.

С. А. Бурлак и А.Б. Пеньковский независимо друг от друга пришли к выводу, что форма времян была использована Пушкиным не только иронически, но и иконически. Ср.: «Может быть, форма на -ян была выбрана поэтом именно для того, чтобы ещё сильнее подчеркнуть устарелость «любовной науки», позволявшей «наслаждаться не любя»?» [Бурлак 2010: 74]; «В этом тексте заслуживает особого внимания $<\ldots>$ форма $<$... $>$ времян, своей безусловной архаичностью материализующая мысль Онегина о холодном разврате как о постыдном явлении, ушедшем в дедовское прошлое. <...> Ср. морфологически стандартную форму времен в содержательно сходном с онегинским, но в полярном, оценочно положительном контексте: «Так своеволием пылая, / Роптала юность удалая, / Опасных алча перемен, / Забыв отчизны давний плен, / Богдана счастливые споры, / Святые брани, договоры / И славу дедовских времен» («Полтава», 1828-1829)» [Пеньковский 2012: 176, сн. 7].

Насколько нам известно, никто из исследователей (возможно, вследствие особенностей русской орфографии) не обращал внимания, что в годы творчества Пушкина в стихах сосуществовали не две, а три формы род. мн. от слова время: времян, времен (через ['э]) и времён. Надежно различить формы времен и времён, разумеется, можно лишь в позиции рифмы и лишь тогда, когда произношение второго 
члена рифменной пары однозначно, т. е. в случае, например, рифмовки стен времен, времен Карфаген, закон времён, времён Парфенон, но не в случае рифмовки име/ён време/ён или време/ён оживле/ён. Ниже мы рассматриваем только абсолютно надежные примеры.

В XVIII - начале XIX в. в стихах встречается исключительно форма времен (отметим изысканную пару времен (природных) феномен в философском стихотворении А.Х. Востокова «Бог в нравственном мире» (1807)). Рассмотрение истории формы времён, как кажется, целесообразно начать с уже упомянутой поэмы А. И. Полежаева «Эрпели» (1830, опубл. 1832).

В шестой главе поэмы описание кавказских событий прерывается своего рода лирическим отступлением («О Эрпели, о Эрпели! И ты уроком для земли!..»), посреди которого автор перебивает себя требованием возвратиться к реальности. Заканчивается глава так:

...Заняться вздумал я мечтою

Нелепой, странной и пустою -

О счастье будущих времен,

А настоящие оставил,

Тогда как первый батальон

Еще палаток не поставил.

Итак, моя галиматья,

Adieu до будущего дня!

По силе стилистической какофонии (безусловно, намеренной) эти строки имеют себе мало равных в тогдашней поэзии. Можно думать, что невиданная рифма времён батальон производила на современников (с поправкой на несопоставимость двух поэтических имен) не меньшее впечатление, чем рифма времян обезьян. Обращает на себя внимание сходство между строкой «Полтавы» И славу дедовских времен и строкой $O$ счастье будущих времён у Полежаева. При этом Пушкин, говоря о «дедовских временах», т. е. о прошлом, в «Евгении Онегине» употребил форму подчеркнуто архаичную, а в «Полтаве» - обычную для поэзии, но едва ли соответствовавшую реальной языковой практике. Напротив, Полежаев, говоря о будущем, употребил форму, за которой в лингвистическом смысле как раз и было будущее. С учетом того, что «Полтава» (как и «Эрпели», «поэма о войне») была опубликована в марте 1829 года, нельзя исключать, что Полежаев был с ней знаком и перед нами - его прямой полемический отклик.

В 1836 г. поэт еще раз использовал форму времён, причем, по-видимому, вновь не без некоторого вызова - как и впоследствии у В.С. Соловьева, переделке подверглась знаменитая державинская формула:

Всему в природе есть закон:

Луна сменяется луной,

И годы мчит река времен

Невозвратимою волной!

(«Красное яйцо»)

Правда, напечатано это стихотворение было только в 1860 г. 
Почти одновременно с «Эрпели», летом 1832 г., вышла поэма В. И. Соколовского (1808-1839) «Мироздание». В этой поэме трижды встречается рифма времён закон; вот один из примеров:

Исполняя Твой закон,

Свет разрушится веками,

И последний вал времен

Расплеснется над гробами.

Как видно, содержание и стиль поэмы Соколовского полностью исключают вероятность того, что форма времён воспринималась им как сниженная. Очевидно, он просто писал так, как говорил, не зная, что в стихах «полагается» использовать вариант с ['э]. В следующем, 1833 году, была издана книга Соколовского «Рассказы сибиряка»; в одном из вошедших в нее стихотворений — «Кто важно в свет вступил при шпаге...» - присутствует рифма времён $\sim$ он.

В истории русской литературы имена Полежаева и Соколовского тесно связаны. Поэты были знакомы и дружны; между ними «было много общего» [Поэты..., т. II: 345]. Приятель Соколовского художник А. В. Уткин — автор замечательного портрета Полежаева. Удивительно, однако, другое. В 1834 г. несколько молодых людей были арестованы по «Делу о лицах, певших в Москве пасквильные стихи». Едва ли не главным пунктом обвинения была остросатирическая песня «Русский император...»; Соколовскому и Уткину ${ }^{5}$ ее исполнение фактически стоило жизни ${ }^{6}$. Большинство исследователей приписывает сочинение «Русского императора» Соколовскому, однако существует и точка зрения, что ее автором был не кто иной, как Полежаев [Безъязычный, Гурьянов 1957].

В том же 1833 году будущий знаменитый религиозный философ В.С. Печерин (1807-1885) пишет поэму «Pot-pourri, или Чего хочешь, того просишь» (опубликованную 28 лет спустя Герценом и Огаревым), где есть такое двустишие:

Я знаю балладу из новых времен,

Как с войском Дон Педро вошел в Лиссабон.

Со второй половины 1830-х гг. форма времён становится обычной, а вскоpe - и преобладающей; в частности, в поэмах М. Ю. Лермонтова «Сашка» (1839) и И.П. Мятлева (1796-1844) «Сенсации и замечания госпожи Курдюковой...» (1840) использована невозможная ранее рифма времён $\sim$ умён.

У Пушкина вариант времён не представлен; впрочем, и имеющийся материал совсем невелик: помимо приведенного отрывка из «Полтавы», можно отметить

${ }^{5}$ В ряде работ среди арестованных по «Делу...» вместо Алексея Васильевича Уткина (17961838 (по другим сведениям, 1836)) упоминается «Н.И. Уткин». В действительности художник Николай Иванович Уткин (1780-1863), выдающийся гравер и, вероятно, побочный сын поэта М.Н. Муравьева, прожил долгую и благополучную жизнь. Источником путаницы, по-видимому, послужила дважды повторенная ошибка в [Поэты..., т. II: 363, 721].

${ }^{6}$ См. об этом: А. И. Герцен, «Былое и думы», ч. II, гл. ХІІ. Герцен, Огарев и некоторые другие обвиняемые были приговорены к ссылке в разные города. 
еще только рифму согбен времен в юношеском стихотворении «Кольна» (1814). Не представлен этот вариант и у Ф.И. Тютчева (1803-1873) - при наличии рифм времен священ («На новый 1816 год» (1815-1816)) и плен времен («Теперь тебе не до стихов...», 1854).

Полежаев и Соколовский, однако, не были первыми поэтами, в стихах которых появилась форма времён. Еще за 11 лет до публикации «Эрпели» и «Мироздания», в поэме Жуковского «Пери и ангел» (1821), представляющей собой перевод второй части поэмы Томаса Мура «Лалла Рук», появляется следующий фрагмент:

И голову потупил он;

И все, что с давних тех времен

В душе ожесточенной спало,

$<\ldots>$

Все вдруг пред ним возобновилось

И в душу, свежее, втеснилось...

Как и в «Мироздании», употребление формы времён не несет в «Пери и ангеле» никакой специальной стилистической нагрузки (в тексте длинной и, в общем, довольно «монотонной» поэмы это нововведение едва ли могло привлечь чье-то особенное внимание); и все же, по крайней мере до появления новых находок, именно Жуковский может с полным правом считаться ее «открывателем».

\section{Заключение}

Два рассмотренных нами сюжета не изоморфны. В случае с $u$-деепричастиями Жуковский следовал, причем в очень ограниченной степени, модели, введенной в поэтическую практику Карамзиным и его единомышленниками, тогда как словоупотребление Пушкина нельзя не признать архаичным в самом точном смысле этого слова. Напротив, в случае с род. пад. мн. ч. слова время Жуковский действительно выступает (пусть, скорее всего, достаточно случайно) в роли первопроходца, Пушкин же просто сохраняет верность традиции, которая к моменту завершения его творческого пути еще оставалась вполне живой. Тем не менее, несмотря на 16 лет разницы в возрасте, в обоих этих аспектах язык Жуковского оказывается более близким к нашему современному языку, чем язык Пушкина.

Предпочтения Пушкина в вопросе об образовании $u$-деепричастий выглядят настолько неожиданными, что заставляют задаться вопросом о том, имелись ли в его идиолекте другие столь же архаические черты. По-видимому, ответ на этот вопрос должен быть положительным. В остающейся, к сожалению, неопубликованной работе [Тихомиров 2015] $]^{7}$, посвященной анализу грамматических предпочтений русских писателей XIX в., рассматривается, в частности, употребление местоимений сей и этот. По данным Д.О. Тихомирова, в пушкинской прозе 20-х - 30-х гг.

${ }^{7}$ Приносим глубокую благодарность С.С. Саю, предоставившему нам возможность ознакомиться с этой интересной работой. 
доля местоимения сей составляет 56,9\%. Эта цифра выглядит совершенно фантастической на фоне написанных в те же годы произведений таких старших современников Пушкина, как А.С. Грибоедов (1795-1829; 32,4\%), Ф.В. Булгарин $(1789-1859 ; 17,1 \%)$ и Н.А. Полевой $(1796-1846 ; 11,7 \%)$, не говоря уж о М.Н. Загоскине (1789-1852; 3,1\%) и И. И. Лажечникове (1792-1869; 1,9\% (!)); разумеется, ничего подобного не наблюдается и у писателей, родившихся позже Пушкина, В. Ф. Одоевского, Гоголя, Гончарова, Лермонтова и других: ни у кого из них доля местоимения сей не превышает 10-11\% [Тихомиров 2015: 40].

Любой человек, говорящий и пишущий на родном языке, в десятках и сотнях точек грамматической системы вольно или невольно делает выбор между конкурирующими формами, конструкциями и т. п.; чаще всего один из возможных вариантов является более старым, другой - более новым. При этом, как справедливо отмечает Д.О. Тихомиров, один и тот же носитель языка «в один и тот же период может быть новатором в одной области и консерватором в другой, и оказываться как новатором, так и консерватором в одной и той же области в разные периоды своего творчества» [Тихомиров 2015: 26-27]; более того, «новатор в области стилистики вполне может быть консерватором в некоторых областях грамматики» [там же: 32]. Применительно к языку пушкинской эпохи даже сам список таких точек вариативности установлен еще далеко не полностью; что же касается предпочтений Пушкина и других поэтов и писателей его времени, они изучены более чем фрагментарно. Как кажется, большая и очень важная работа по описанию «языковых личностей» Пушкина и его современников только еще начинается.

\section{Литература}

Абдулхакова Л.Р. Развитие категории деепричастия в русском языке : дис. ... докт. филол. наук. Казань, 2007.

Безъязычный В.И., Гурьянов В.П. Кто был автором песни «Русский император»? // Вестник МГУ, историко-филологическая серия. 1957. № 1. С. 179-184.

Булаховский Л.А. Русский литературный язык первой половины XIX века. Фонетика. Морфология. Ударение. Синтаксис. Т. ІІ. Киев, 1948.

Бурлак С.A. [Решение задачи 10 для 10-11 классов] // «Русский медвежонок»-2009. Задачи, решения, информация, статистика / Сост. Е.В. Муравенко, И. С. Рубанов, И. Ф. Богдалов. Киров, 2010. С. 73-74.

Гиллельсон М. И. Молодой Пушкин и арзамасское братство. Л., 1974.

Греч 1827 - Практическая русская грамматика, изданная Николаем Гречем. СПб., 1827.

Греч 1834 - Практическая русская грамматика, изданная Николаем Гречем. Второе издание, исправленное. СПб., 1834.

Добровольский Д. О. К динамике узуса (язык Пушкина и современное словоупотребление) // Русский язык в научном освещении. 2001. № 1(1). С. 161-178.

Жуковский $B . A$. Полное собрание сочинений и писем : в 20 т. Т. 1. Стихотворения 1797-1814 годов / Ред. О. Б. Лебедева, А.С. Янушкевич. М., 1999. 
Касаткин Л. Л., Касаткина Р. Ф. Язык - свидетель беспристрастный: Проблема авторства сказки «Конёк-Горбунок» // Известия РАН. Серия литературы и языка. 2012. Т. 71. № 5. С. 23-45.

Касаткин Л. Л., Касаткина Р. Ф. Псковские диалектизмы в сказке «Конёк-Горбунок» как свидетельство авторства А. С. Пушкина // Смыслы, тексты и другие захватывающие сюжеты. Сборник статей в честь 80-летия И.А. Мельчука. М., 2012. C. $273-287$.

Обнорский С. П. Очерки по морфологии русского глагола. М., 1953.

Падучева Е. В. Русский литературный язык до и после Пушкина // G. Ressel (ed.). A. S. Puškin und die kulturelle Identität Rußlands. Frankfurt/Main, 2001. C. 97-108.

Пеньковский А.Б. Исследования поэтического языка пушкинской эпохи: филологические исследования. М., 2012.

Периов Н. В. Сказка П.П. Ершова «Конек-Горбунок» в лингвистическом и историко-литературном освещении // Перцов Н.В. Лингвистика, поэтика, текстология: избранные статьи. М., 2015. С. 587-604.

Поэты... - Поэты 1820-х - 1830-х годов. В 2 тт. / Биогр. справки, сост., подгот. текста и примеч. В.С. Киселева-Сергенина. Под общей редакцией Л. Я. Гинзбург. Изд. 2-е. Л., 1972.

ППК 1828-1830 - Пушкин в прижизненной критике. 1828-1830 / Под общей редакцией Е. О. Ларионовой. СПб., 2001.

Серебряная И.Б. Грамматические оценки в русской критической литературе 1-й половины XIX века (морфология). Казань, 2012.

Тихомиров Д. О. Отражение общеязыковых изменений в индивидуальном языке писателей XIX века: корпусное исследование. Рукопись. 2015.

Черейский Л. А. Пушкин и его окружение. Издание 2-е, дополненное и переработанное. Л., 1988.

\author{
Il'ya B. Itkin \\ Institute of Oriental Studies, RAS / \\ National Research University Higher School of Economics \\ (Moscow, Russia) \\ ilya.borisovich.itkin@gmail.com
}

\title{
ZHUKOVSKY THE INNOVATOR AND PUSHKIN THE ARCHAIST (two studies from the history of the language of Russian poetry)
}

The article considers the works of poets from the $18^{\text {th }}$ and early $19^{\text {th }}$ century in terms of the variability of two points in the grammatical system of the Russian language: (1) the formation of adverbial participles from prefixed verbs ending in -ümu (the pattern вошед, пришед versus войдя, придя) and (2) the choice of the genitive plural of the noun время with a stressed or unstressed vowel (времян, времен with ['э] versus or времён). 
The forms ending in - $\breve{\partial} я$ entered the Russian poetry in the late 1780s thanks to Karamzin and the poets of his circle, primarily Dmitriev. In the first decades of the $19^{\text {th }}$ century, these forms were already quite common: in particular, they are found in the later works of Derzhavin and Khvostov, as well as in Zhukovsky's poetry of the "Arzamas» period (1813-1818). Against this background, the complete absence of such forms in Pushkin's poetry appears surprising. A comparison with Pushkin's prose, in which forms ending in -шед are also absolutely dominant, allows us to conclude that we are not dealing with a case of conscious archaization, but rather one of a real usage. As for the genitive case of the word время, until the beginning of the $1830 \mathrm{~s}$, the base form was времен. The initially competing form времян was perceived as clearly outdated (or even simply as "wrong") as early as the 1820s; when he used this form in "Eugene Onegin", Pushkin raised objections from critics who did not understand his notion of parody. In the 1830s, the form времён аppears in the verses of A.I. Polezhaev and V.I. Sokolovsky, and it spread very quickly. The earliest known example of the use of the form времён, however, is found in the works of V.A. Zhukovsky (the poem «Peri and the Angel», 1821); in Pushkin's poems, this form is absent. Thus, according to both parameters considered here, Zhukovsky's language is closer to the modern standard than Pushkin's. These examples show that the idea of Pushkin as an innovator in the Russian language, while true on the whole, nonetehless requires clarification in many details.

Keywords: A. S. Pushkin, V. A. Zhukovsky, Russian poetry, evolution of the Russian language, grammatical variability, archaism, innovation.

\section{References}

Abdulkhakova L.R. Razvitie kategorii deeprichastiya v russkom yazyke. Diss. ... dokt. filol. nauk [Development of the category of adverbial participle in the Russian language]. Kazan, 2007. (In Russ.)

Bez"yazychnyy V.I., Gur'yanov V.P. [Who was the author of the song «Russian emperor»?]. Vestnik $M G U$, istoriko-filologicheskaya seriya, 1957, no 1, pp. 179-184. (In Russ.)

Bulakhovskiy L.A. Russkiy literaturnyy yazyk pervoy poloviny 19 veka. Fonetika. Morfologiya. Udarenie. Sintaksis. T. II. [Russian Literary Language of the first half of the $19^{\text {th }}$ century. Vol. 2]. Kiev, 1948. (In Russ.)

Burlak S. A. [Solution of the puzzle no 10 for the students of grade 10-11]. «Russkiy Medvezhonok»-2009. Zadachi, resheniya, informatsiya, statistika [«Russian Bear Cub»2009. Puzzles, solutions, information, statistics]. Kirov, 2010, pp. 73-74. (In Russ.)

Chereyskiy L.A. Pushkin i ego okruzhenie [Pushkin and his surroundings]. Second edition, supplemented and revised. Leningrad, 1988. (In Russ.)

Dobrovol'skiy D. O. [Towards the dynamics of usage (the language of Pushkin and the modern word usage)]. Russkiy yazyk v nauchnom osveshchenii, 2001, no 1(1), pp. 161178. (In Russ.)

Gillel'son M. I. Molodoy Pushkin i arzamasskoe bratstvo [Young Pushkin and the Arzamas brotherhood]. Leningrad, 1974. (In Russ.) 
Kasatkin L. L., Kasatkina R.F. [Language is an impartial witness: the problem of the authorship of the fairy-tale «The Little Humpbacked Horse»]. Izvestiya RAN. Seriya literatury i yazyka, 2012, vol. 71, no 5, pp. 23-45. (In Russ.)

Kasatkin L.L., Kasatkina R.F. [Pskov dialecticisms in the fairy-tale «The Little Humpbacked Horse» as a witness of A. S. Pushkin's authorship]. Smysly, teksty i drugie zahvatyvayushchie syuzhety. Sbornik statej v chest' 80-letiya I. A. Mel'chuka [Meanings, texts and other thrilling plots. A collection of articles in honor of I. A. Melchuk's $80^{\text {th }}$ anniversary]. Moscow, 2012, pp. 273-287. (In Russ.)

Obnorskij S.P. Ocherki po morfologii russkogo glagola [Essays on the morphology of the Russian verb]. Moscow, 1953. (In Russ.)

Paducheva E. V. [Russian literary language before and after Pushkin]. A.S. Puškin und die kulturelle Identität Rußlands [A. S. Pushkin and the cultural identity of Russia]. Ed. by G. Ressel. Frankfurt/Main, 2001, pp. 97-108. (In Russ.)

Pen'kovskiy A.B. Issledovaniya poeticheskogo yazyka pushkinskoy epokhi: filologicheskie issledovaniya [Studies of the poetic language of the Pushkin's epoch: philological studies]. Moscow, 2012. (In Russ.)

Pertsov N.V. [P.P. Ershov's fairy-tale «The Little Humpbacked Horse» in linguistic and historical-literature interpretation]. Pertsov N. V. Lingvistika, poetika, tekstologiya: izbrannye stat'i [Pertsov N. V. Linguistics, poetics, text linguistics: selected articles]. Moscow, 2015, pp. 587-604. (In Russ.)

Poety 1820-h - 1830-h godov. V 2 tt. [Poets of 1820s - 1830s. In 2 volumes]. Ed. by L.Ya. Ginzburg. Second edition. Leningrad, 1972. (In Russ.)

Prakticheskaya russkaya grammatika, izdannaya Nikolaem Grechem [Practical grammar of Russian, published by Nikolay Grech]. St-Petersburg, 1827. (In Russ.)

Prakticheskaya russkaya grammatika, izdannaya Nikolaem Grechem. Vtoroe izdanie, ispravlennoe [Practical grammar of Russian, published by Nikolay Grech. Second edition, Corrected]. St-Petersburg, 1834. (In Russ.)

Pushkin v prizhiznennoy kritike. 1828-1830 [Pushkin in his lifetime critics. 18281830]. Ed. by E. O. Larionova. St-Petersburg, 2001. (In Russ.)

Serebryanaya I. B. Grammaticheskie otsenki v russkoy kriticheskoy literature 1-y poloviny 19 veka (morfologiya) [Grammatical assessments in the Russian critical literature of the first half of the $19^{\text {th }}$ century (morphology)]. Kazan, 2012. (In Russ.)

Tikhomirov D. O. Otrazhenie obshcheyazykovyh izmeneniy v individual'nom yazyke pisateley 19 veka: korpusnoe issledovanie. Manuscript. 2015. (In Russ.)

Zhukovskiy V.A. Polnoe sobranie sochinenij i pisem : v 20 t. T. 1. Stihotvoreniya 1797-1814 godov [Full collection of works and letters in 20 volumes. Vol. 1. Poems of 1797-1814]. Moscow, 1999. (In Russ.) 